\title{
NEW DATA ON THE DUSTY WINGS FROM AFRICA AND EUROPE (INSECTA, NEUROPTERA, CONIOPTERYGIDAE)
}

\author{
V. J. Monserrat*
}

\begin{abstract}
New data on the biology, distribution and sometimes morphology of 43 Palaearctic and Afro-tropical dusty wings species are given. A great variability margin in the presenceabsence and extension of scale like hairs in male antennae of some species of subgenus Xeroconiopteryx has been detected and such character (very frequently used) is proposed to be rejected as a definitive taxonomical character to differentiate problematic species of this subgenus with very similar male genitalia. On the contrary, vertex sedation and structures (figured for some different species) seem to be a very good character to be taking into account. Coniocompsa silvestriana Enderlein, 1914 = (Coniocompsa smithersi Meinander, 1972) n. syn. and Parasemidalis alluaudina (Navás, 1912) = (Semidalis alluaudina Navás, 1912 = Parasemidalis fusca Meinander, 1963) $n$. syn. are proposed as new synonymies. Helicoconis canariensis n. sp. and Coniopteryx canariensis n. sp. from Canary Islands and Semidalis pallidicornis $\mathrm{n}$. sp. from Uganda are described as new species.
\end{abstract}

Key words: Neuroptera, Coniopterygidae, Afro-tropical, Palaearctic, Faunistics, Chaetotaxia, Taxonomy.

\section{RESUMEN}

\section{Nuevos datos sobre los coniopterígidos de África y Europa} (Insecta, Neuroptera, Coniopterygidae)

Se aportan nuevos datos sobre la biología, distribución y morfología de 43 especies de coniopterígidos Paláearticos y Afrotropicales. Se pone de manifiesto la existencia de una marcada variabilidad en la presencia-ausencia y extensión de setas escuamiformes en las antenas de los machos de varias especies del subgénero Xeroconiopteryx, por lo que se propone desechar este carácter taxonómico (muy frecuentemente usado) para diferenciar las especies conflictivas con similar genitalia masculina dentro de este subgénero. Por el contrario, la quetotaxia y las estructuras del vértex (anotado para diferentes especies) sí representa un buen carácter taxonómico a tener en cuenta. Coniocompsa silvestriana Enderlein, $1914=($ Coniocompsa smithersi Meinander, 1972) n. syn. y Parasemidalis alluaudina (Navás, 1912) = (Semidalis alluaudina Navás, $1912=$ Parasemidalis fusca Meinander, 1963) $n$. syn. se proponen como nuevas sinonimias. Se describen como nuevas especies a Helicoconis canariensis n.sp. y Coniopteryx canariensis n.sp. de las Islas Canarias y a Semidalis pallidicornis n.sp. de Uganda.

Palabras clave: Neuroptera, Coniopterygidae, Afrotropical, Paleártico, Faunística, Quetotaxia, Taxonomía.

* Departamento de Biología Animal I. Facultad de Biología. Universidad Complutense. 28040 (Madrid). E-mail: ARTMAD@bio.ucm.es 


\section{Introduction}

The family Coniopterygidae is one of the most interesting one within the order Neuroptera due to its wide (almost cosmopolitan) geographical distribution, its high number of species and individuals of which its populations usually consist, and in particular because of its importance in the control of small phytophagous pests.

It is obvious that the best known fauna is the European (Aspöck et al., 1980), followed by the western Palaearctic, Afro-tropical and remaining Regions. Ever since the article of Monserrat (1995), where an up date of the knowledge and relationship between West Palaearctic and Afro-tropical coniopterygid fauna was indicated, the number of published papers on the coniopterygid fauna of the West Palaearctic has grown (Aspöck et al., 2001) but only a few articles have been published on the Afro-tropical fauna: Meinander (1998a, b), Sziráki (1994), Sziráki \& Greve (1996), Monserrat (1998), Ohm \& Hölzel (1997, 1998, 1999). Many biogeographical interesting aspects on the relationships among Palaearctic, Afro-tropical and Oriental coniopterygid fauna have been reported by Aspöck \& Hölzel (1996), Monserrat (1996), Meinander (1996), Sziráki (1998) and Hölzel (1998). All these papers have contributed with new data on the biology, taxonomy, morphology, variability, distribution and biogeography of many species, but in most of species the level of knowledge is still very limited and not very satisfactory, the degree of intra-specific variability is still underestimated (Aspöck \& Hölzel, 1996; Meinander, 1996), and new species are found, even in well sampled territories, as now it is demonstrated from Canary Islands. In this current publication, we are attempting to contribute new data on taxonomy, geographical distribution, biology, morphology or variability of some species of this family.

\section{Materials and methods}

Material from many collections and institutions has been studied, and to indicate where this material is located and to which institution it belongs to, the following abbreviations are used:

DZUL: Universidad de La Laguna (Tenerife)*.

ET: $\quad$ Collection of E.J.Tröger (Freiburg).

ETV: Escuela Técnica de Ingenieros Agrónomos (Valencia).

MCNM: Museo Nacional de Ciencias Naturales (Madrid)**.

VM: Author's collection, Universidad Complutense (Madrid)
* Material from Las Cañadas belongs to the research project "Inventario de la fauna de invertebrados del P.N. del Teide".

** Material from La Palma Island belongs to the research project "Inventario y estudio de la fauna invertebrada del P.N. de la Caldera de Taburiente".

For each species a general previous geographic distribution and known plants substrate are noted. For the enumeration of the studied material, the contributed data are recorded alphabetically and chronologically with the following order: country, state, county, province or islands, location of the capture, date of the capture, number of $\sigma^{\pi} \sigma^{\pi}$ and of 우 studied, the collector and institution to which the material belongs to abbreviations mentioned above. While listing the material studied, an asterisk $(*)$ is used to indicate the countries where some of the included species where previously unknown, and with male symbol $\left(\sigma^{7}\right)$, a female symbol ( $O$ ) and $(\mathrm{h})$ denotes those specimens $\left(\sigma^{\top} *, 0 *\right)$ chosen to serve for figures of male genitalia, female genitalia or head morphology respectively.

The terminology used for the venation and male and female genitalia of the different species studied is that which is used for this family by Meinander (1972, 1990).

\section{Studied species}

Aleuropteryginae Enderlein, 1905

Aleuropterygini Enderlein, 1905

Aleuropteryx loewii Klapalek, 1894

An expansive Nord-Mediterranean species usually recorded on Pinus and on other conifers.

SPAIN: Madrid, Rivas Vaciamadrid, Cerro del Telégrafo, 26.III.1997 $10^{7}$ on Ephedra fragilis, J.L. López (VM). Murcia, Atamaría, 13.V.1994 1 ㅇ on Pinus halepensis, L. Díaz Aranda (VM), Calblanque, 13.V.1994 1 우, 12.VII.1994 10", 2 우 우 on Pinus halepensis, L. Díaz Aranda (VM), Campillo de Almendro, 13.V.1994 1 ㅇ on Pinus halepensis, L. Díaz Aranda (VM), Torrepacheco, 10.V.1994 4 ㅇ $ᄋ$ on Pinus halepensis, L. Díaz Aranda (VM).

\section{Aleuropteryx minuta Meinander, 1965}

A species known from Saharahui Arabic Republic and Spain, very strongly associated with dry and saline habits and recorded on Tamarix, Pistacea, Phoenix, Ceratonia and Zizyphus.

SPAIN: Almería, Llano Don Antonio, 10.V.1994 $20^{7} \sigma^{7}$ on Tamarix gallica, L. Díaz Aranda (VM), 9.VI.1994 20" $0^{\prime \prime}, 1$ 우 on Tamarix gallica, L. Díaz Aranda (VM), 14.VII.1994 $20^{7} 0^{7}$, 1 o on Tamarix gallica, L. Díaz Aranda (VM), Santa María de Nieva, 14.VII.1994 1 o on Tamarix gallica, L. Díaz Aranda (VM). 


\section{Aleuropteryx juniperi Ohm, 1968}

A Holomediterranean species, recorded in Pennsylvania and Virginia, USA (probably due to human action). Usually collected on Cupresaceae (Juniperus \& Cupresus), but also on other conifers, specially Pinus, and also on many other plants (Quercus, Castanea, Ulmus, Ceratonia, Pistacea, Citrus, Olea, etc.), showing a very high ecological versatility.

SPAIN: Murcia, Rambla de Miñarro, 8.VI.1994 $10^{\pi}$ on Olea europaea, L. Díaz Aranda (VM).

\section{Aleuropteryx iberica Monserrat, 1977}

A species known from the Iberian Peninsula and Morocco, strongly associated to Mediterranean sclerophilous Quercus spp.

SPAIN: Almería, El Marchal, 10.VI.1996 1 우 on Quercus ilex L. Díaz Aranda (VM).

\section{Aleuropteryx remane Rausch, Aspöck \& Ohm, 1978}

A species known from East of Spain, from dry and thermic areas usually without arboreal vegetation, and sometime recorded on Artemisa.

SPAIN: Almería, El Marchal, 10.VI.1994 1 우 on Quercus coccifera, L. Díaz Aranda (VM). Zaragoza, Pina de Ebro, 20.VII.1993

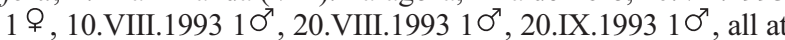
light in a Juniperus thurifera wood, J. Blasco (VM).

\section{Coniocompsini Enderlein, 1905}

\section{Coniocompsa silvestriana Enderlein, 1914}

This almost unknown species was inadequately described from Guinea Conakry by Enderlein (1914) and its deposition type is unknown. This species was re-described by Meinander (1975a) on the basis of samples from Nigeria and has been frequently associated with Coniocompsa smithersi Meinander, 1972 (Monserrat \& Díaz Aranda, 1988; Monserrat, 1989; Meinander, 1998b) a species frequently recorded from the centre and south of Africa (Kenya, Zimbabwe, South Africa, Tanzania and Equatorial Guinea).

We fully agree with the arguments given by Meinander (1998b) and consider both species definitively synonymous.

Coniocompsa silvestriana Enderlein, 1914: 226

$=($ Coniocompsa smithersi Meinander, 1972: 99) n. syn.

MOZAMBIQUE*: I.Inhaca, 17-26.VIII.1999 10", 1 우 V.J. Monserrat, at light (VM). UGANDA*: Bundibugyo, Semliki Forest, $0^{\circ} 48^{\prime} \mathrm{N} 30^{\circ} 8^{\prime} \mathrm{E}, 670 \mathrm{~m}, 5-12 . \mathrm{II} .19971{ }^{\circ} \mathrm{T}$. Wagner (VM) on Ficus capensis. Masindi, N Sonso, Budongo Forest, $1^{\circ} 45^{\prime} \mathrm{N} 31^{\circ} 35^{\prime} \mathrm{E}, 1.200 \mathrm{~m}, 19-30 . \mathrm{VI} .199510^{\prime \prime}$, 32우 우 $\mathrm{T}$. Wagner (VM), 11-20.VII.1995 10", 4 우 우 T. Wagner (VM), 15-25.I.1997 $60^{x} 0^{x}, 15$ ㅇ ㅇ T. Wagner (VM), of them 33 on
Cynometra alexandri, 16 on Rinorea beniensis, 4 on Trichilia rubescens, 4 on Tecla nobilis and 2 on Rinorea ardisiifolia.

These specimens have highly variable wing pigmentation; from individuals with almost clear wings to specimens with strongly dark spotted wings. Their peritrophic membranes had abundant and highly macerated remains of arthropods, particularly: insects, pollen grains and fungal spores and sporangia.

Fontenelleini Carpentier \& Lestage, 1928

Helicoconis (Ohmopteryx) pseudolutea Ohm, 1965

A Southern West Palaearctic species, usually from dry and thermic areas, mostly collected at light, but also on Juniperus, Larix, Pinus, Populus, Castanea, Quercus, Ceratonia, Daphne, Ulmus, Celtis, Corylus, Pistacea \& Olea, probably lives on low-herbaceous vegetation.

PORTUGAL: Amarante, Serra do Marao, Torno, Ribeiro do Ramalhoso, 7.VII.1990 $10^{\pi}$ at light, L. Terra (VM). SPAIN: Almería, El Marchal, 10.VI.1994 50 $0^{7} 0^{7}, 4$ 우 우, on Quercus ilex, L. Díaz Aranda (VM). Murcia, Pliego, 7.VI.1994 10", 1 ㅇ on Pinus halepensis, L. Díaz Aranda (VM), Succina, 16.V.1994 $10^{2}$ on Pinus halepensis, L. Díaz Aranda (VM).

\section{Helicoconis (Fontenellea) canariensis n. sp.}

Recently Monserrat (1995) cites a brachipterous $\circ$ as Helicoconis sp. from Tenerife. After the finding of two also brachypterous $\sigma^{\pi} \sigma^{\pi}$ specimens, a new species is confirmed, having assigned the cited $q$ to the now collected males.

TYPE: SPAIN: Tenerife, Las Cañadas, El Portillo, 2,100 m, (UTM 346, 3131), 4.X.1995 10", A. Camacho (VM).

PARATYPES: SPAIN: Tenerife, Las Cañadas, La Fortaleza, 1,960 m, (UTM 343.15, 3132.82), 6.X.1995 10', N. Zurita (VM), Teno, 230 m, (UTM 315, 3138), 5.XI.1987 1우, A. Fjellberg (VM).

DiAGNosis: Brachipterous-apteral species (Fig. 1-2) whose males have 30 flagelomera in the antennae. The penis is not very fused interiorly, the styles are clearly bifurcated and their parameres have a ventral tooth (Fig. 3-9).

DESCRIPTION: The general aspect of the body is very long compared to the winged species as an adaptation to walk. It is brown caramel colour with a darker head, except for the forehead, the vertex and the middle zone of the clypeus that are very pale because of being very weakly sclerotized. The eyes are very small in relation to the winged species. The maxillary and labial palpi are pale brown, and very long especially in the $\sigma^{\prime}$. The antennae are uniformly brown in the $\sigma^{\prime \prime}$, and progressively darken in the $\$$, where the five ultimate segments are dark 


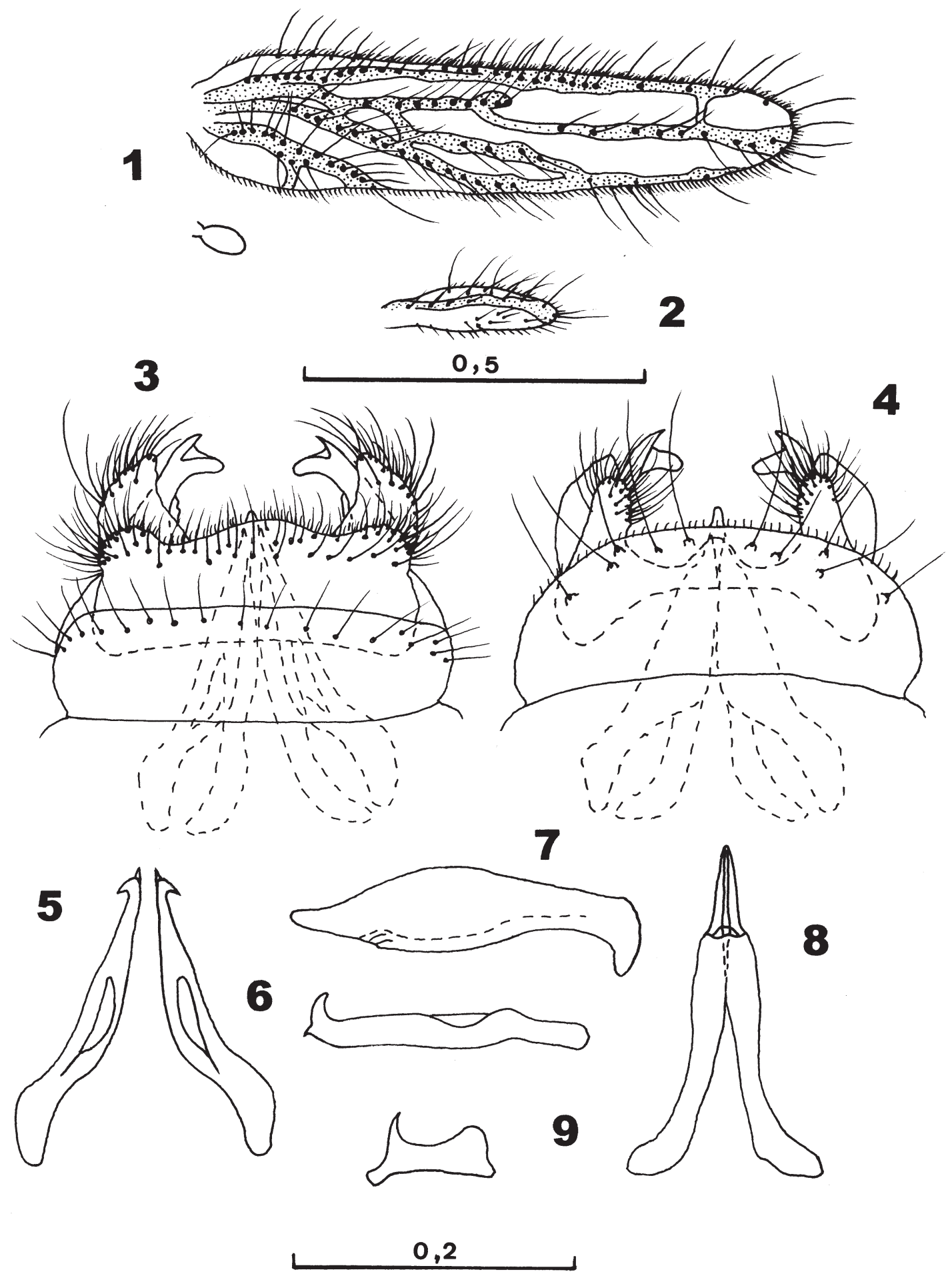

Figs. 1-9.- Helicoconis canariensis n. sp. 1: Male wings. 2: Female forewing. 3: Male abdominal apex, dorsal. 4: Ditto, ventral. 5: Parameres, dorsal. 6: Ditto, lateral. 7: Penis, lateral. 8: Ditto, ventral. 9: Stylus, lateral. Scale in mm.

Figs. 1-9.- Helicoconis canariensis n. sp. 1: Alas del macho. 2: Ala posterior de la hembra. 3: Ápice abdominal del macho, dorsal. 4: Ditto, ventral. 5: Parámeros, dorsal. 6: Ditto, lateral. 7: Pene, lateral. 8: Ditto, ventral. 9: Estilo, lateral. Escalas en mm. 
brown. The scape is sub cylindrical, curved outwards and one and a half times as long as it is wide in the $\sigma^{\pi}$. It is shorter in the $\circ$. The pedicel is cylindrical, somehow longer than wider in the $\sigma^{7}$, and shorter and fusiform in the $\odot$. The flagelomera in the $\sigma^{\pi} \sigma^{\pi}$ are one and a half times longer than wide, the most distal ones being somehow shorter. And in the $ᄋ$ they are only slightly longer than wide. In the $0^{\pi} 0^{\pi}$ there are 30 in number, and 24 in the 9 .

The thorax is very elongate, the prothorax being longer than the pterothorax, causing a marked separation of the first pair of legs from the rest, especially in the $\sigma^{x}$. The legs are brown, and slightly darker than the thorax. In the 9 the tip of the tibias is darker. The legs are a lot more elongate compared to the well-winged species, especially in the $0^{x}$. The coxes of the first pair of legs are very elongate, in the $\sigma^{x}$ in particular. The forewings of the male are elongate, proportionately hairy and have rudimentary venation in which only a few veins can be made out (Fig. 1). The hind wings are reduced to a scale-form membrane (Fig. 1). In the $\odot$ the forewings are even more reduced (Fig. 2) and the hind wings have disappeared.

The abdomen is sub cylindrical in the $0^{7}$, and globular in the 9 . In the male genitalia (Fig. 3-9) the $9^{\text {th }}$ segment is weakly sclerotized. The ventral processes of the $9^{\text {th }}$ sternite are digit-form and are covered with abundant setae. The ectoproct is ovoid from the lateral view, with a more sclerotized anterior margin, especially in the ventral region where it forms a narrow bridge embedded in the $9^{\text {th }}$ segment and which is fused with the hypandrium in the middle zone (Fig. 3). The ventral process of the ectoproct is large, sub conical, and slightly arched towards the midline (Fig. 4). The styli are short, straight from the lateral view and curved towards the inside, bifurcated at the end, with a sharp dorsal branch and the other ventral one flat and obtuse (Fig. 3, 4, 9). The hypandrium is triangular in lateral view and semicircular in ventral, has a line of long setae (Fig. 4). The parameres are slightly sinuous in lateral view; their caudal end curves upward and outward and has an inferior tooth (Fig. $5,6)$. The penis is short, wide and progressively thins out towards its end in lateral view and subtly from the dorsal view (Fig. 7, 8). The $Q$ has a bursa copulatrix that is curved from the lateral view, similar to that which is described in other species.

DiSCUSSION: There are several apterous and brachypterous species described in this genus: $H$. aptera Messner, 1965 of Bulgaria, Turkey and Turkmenistan, H. hirtinervis Tjeder, 1960 from
Europe and Turkey, H. maroccana (Carpentier \& Lestage, 1928) from Morocco or H. salti Kimmins, 1950 from Uganda. H. canariensis n.sp. seems closer to $H$. maroccana, but its wings and venation are a lot more reduced. The flagellum of its antennae has more segments (30 instead of to 25), the penis is a lot less fused interiorly and the styli are clearly bifurcated (Carpentier \& Lestage, 1928, Ohm, 1965, Meinander, 1972). Judging from the male genitals, it seems to be also close to $H$. algirica Meinander, 1976 from Algeria and H. panticosa (Ohm, 1965) which is known from Spain and Turkey, but they are well winged species and in its male genitalia the penis narrows abruptly from the lateral view and the parameres do not have the ventral tooth (Ohm, 1965, Meinander, 1972, 1976).

Regarding to the biology of this new species the date of the collection of the specimens (X-XI) stands out as interesting. They were collected on the grass at $230 \mathrm{~m}$ and in the coolest zones of Las Cañadas at $1,960 \mathrm{~m}$ with window and drop traps, and where the vegetation was predominantly composed of brooms and other associated plants (Chamaecytisus proliferus, Cistus osbaeckifolius, Spartocytisus supranubius, and Adenocarpus viscosus, Juniperus cedrus, Ferula linkii, Nepeta teydea).

Coniopteryginae Burmeister, 1839

Coniopterygini Burmeister, 1839

Nimboa albizziae Kimmins, 1952

Species known from Kenya, Zimbabwe, Zambia, and South Africa, sometime recorded on Albizzia. The specimens which are cited agree with that which is noted by Monserrat (1998) and significantly enlarge its geographic distribution.

MALI*: Bandiagara, 22.VII.1997 20 $0^{\pi}$. Douna, Zinzana,

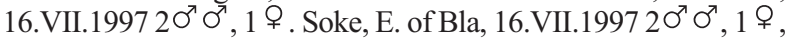
all collected on Dicrostochys glomerata by V.J. Monserrat (VM).

\section{Nimboa macroptera Aspöck \& Aspöck, 1965}

A species known of dry areas from Egypt, Sudan, Lebanon, Saudi Arabian and Spain (Canary Islands, Tenerife). This conflictive and variable species was proposed by Monserrat (1995) as prior synonymy of Nimboa vartianorum Aspöck \& Aspöck, 1965 recorded from Afghanistan, Saudi Arabia, Oman and Iran. The current new recorded specimens from Crete come into the known variability of this species, and probably belong to the not described and probably new species recorded from Rhodes by Aspöck et al. (1980: 317).

GREECE: S. Crete, Gavdos, 23.V.1999 20" 0", 25.V.1999 10", 1 ㅇ on Pistacia lentiscus, E.J. Tröger (ET, VM). 


\section{Nimboa espanoli Ohm, 1973}

A species known from S.E. Spain, Canary I., Morocco, Nigeria, and South Africa (Transvaal). Mostly collected in warm and dry areas, on Mediterranean fanerophytes or nanofanerophytes (Chamaerops humilis, Pinus halepensis, Juniperus oxycedrus, Quercus rotundifolia, Ceratonia siliqua, Pistacea lentiscus, P. terebinthus), also at light. In Africa recorded on cotton.

MALI*: Bandiagara, 18.VII.1997 20 $0^{\pi}, 1$ 우 on Baissea multiflora, V.J. Monserrat (VM). Soke, E. of Bla, 16.VII.1997 $2 \sigma^{\top} \sigma^{\pi}, 1$ on Combretum micranthum, V.J. Monserrat (VM) Somo, E. of San, 16.VII.1997 10", 2 우 우 on Dicrostochys glomerata, V.J. Monserrat (VM). SPAIN: Córdoba, Luque, 8.IX.1995 1 우 on Cupresus sempervirens, M. Baena. Granada, La Herradura, 8.IX.2001 1 \% at light, V.J. Monserrat (VM) Jaén, Sierra del Ahillo, Alcaudete, 1.VII.1995 30" $0^{\pi}, 2$ 우 $ᄋ$ on Echinospartum boissieri, M. Baena (VM). Murcia, Rambla de Minaros, 12.VII.1994 $10^{\text {T }}$ on Nerium oleander, L. Díaz Aranda (VM).

\section{Nimboa marroquina Monserrat, 1985}

Species known from Morocco and South Africa, and sometime recorded on Phoenix. The specimens now cited agree with the description of the species and with the recorded specimens from Kruger National Park in South Africa (Monserrat, 1985, 1995). Recently Meinander (1998b) describes the species: N. manselli from this same National Park, without referring to the species which we now refer to, and with which it is most likely synonymous.

MOZAMBIQUE*: I.Inhaca, 25-26.VIII.1999 20 $0^{\pi} 0^{x}, 1$ 우 at light, V.J. Monserrat (VM).

Coniopteryx (Xeroconiopteryx) stuckenbergi Tjeder, 1957

Species known from South Africa, Equatorial Guinea, Tanzania, and Aldabra Island. Recorded on Acacia.

UGANDA*: Masindi, N Sonso, Budongo Forest, $1^{\circ} 45^{\prime} \mathrm{N} 31^{\circ}$ 35'E, $1.200 \mathrm{~m}, 19-30$.VI.1995 $40^{7} \sigma^{7} *(\mathrm{~h}), 3$ 우 $ᄋ$ T. Wagner (VM), on Cynometra alexandri, 11-20.VII.1995 10" T. Wagner (VM), on Rinorea ardisiifolia.

Subgenus Xeroconiopteryx Meinander, 1972 is one of the most conflictive into Coniopterygidae. Meinander (1981) makes an excellent contribution to clarify it, and makes 10 groups species for the 41 species of such subgenus. Later Meinander (1990) lists 48 species, and many other have recently been described, specially in the now studied area (Sziráki, 1994, 1997, Monserrat, 1995, 1996, 1998, Sziráki \& Greve, 1996, Meinander, 1998a, b). In many cases some of these descriptions are based on the very little amount of specimens, and without a real difference with other older, and sometime very variable species, or with very few differences between one species and other. One of the morphological characters more used for these authors is the presence-absence and distribution of scale like hairs in male antennae in order to differentiate new species, and one from each other. We consider that such character is very difficult to see in many individuals (not enough sclerotized), and we have detected a large variability in this character in some species. So, in some of the now studied male specimens of Coniopteryx stuckenbergi the scale like hairs cover almost the pedicel (Fig. 20) and not only its apex as Meinander (1972) reports (see also Coniopteryx atlasensis and Coniopteryx perisi), and we propose that such character must be rejected as a final and valuable taxonomical character to differentiate some of the most problematic species of this subgenus with a very similar male genitalia, and probably a lot of new synonymies will be proposed.

On the other hand, vertex sedation and structures seem to be very good characters to be taking into account. Vertex morphology has not only been used to describe many new species in different coniopterygids genera as Neosemidalis, Semidalis or Heteroconis, but also in Coniopteryx, and specially in its subgenus Xeroconiopteryx (Meinander, 1972, 1975a, b, 1983, 1990, 1998b, Monserrat, 1976, 1995, 1989, Sziráki, 1997, etc.) but only conspicuous structures have been normally described, however chaetotaxia of vertex and other micro-structures must be appreciated as a good character to differentiate some species as it is sowed in figures 10-17, and surely will be a new field to next taxonomical studies.

Coniopteryx (Xeroconiopteryx) atlasensis Meinander, 1963

Recorded from Southern limits of west Palaearctic: Europe (Iberian Peninsula, Crete), Morocco, Canary Islands (Fuerteventura, La Palma), Turkey, and Central Asia (Afghanistan, Iran, Tadshikistan, Kazakhstan, Aserbeidshan). Associated to dry and warm Mediterranean habitats. In Europe imagos mostly collected at light, and sometimes also found on Pinus halepensis, Quercus rotundifolia, Ceratonia siliqua and Tamarix gallica, Juniperus thurifera, Populus nigra, Quercus coccifera, Q. faginea, Ulmus minor, Pistacea lentiscus and Olea europea. In Africa and Asia were found on Tamarix, Juniperus, Pinus, Quercus, Tetraclinis, Olea and Ceratonia. Probably, this species lives in low vegetation.

Male pedicel of some studied specimens has not scale like hairs, and typical form of the basal anten- 

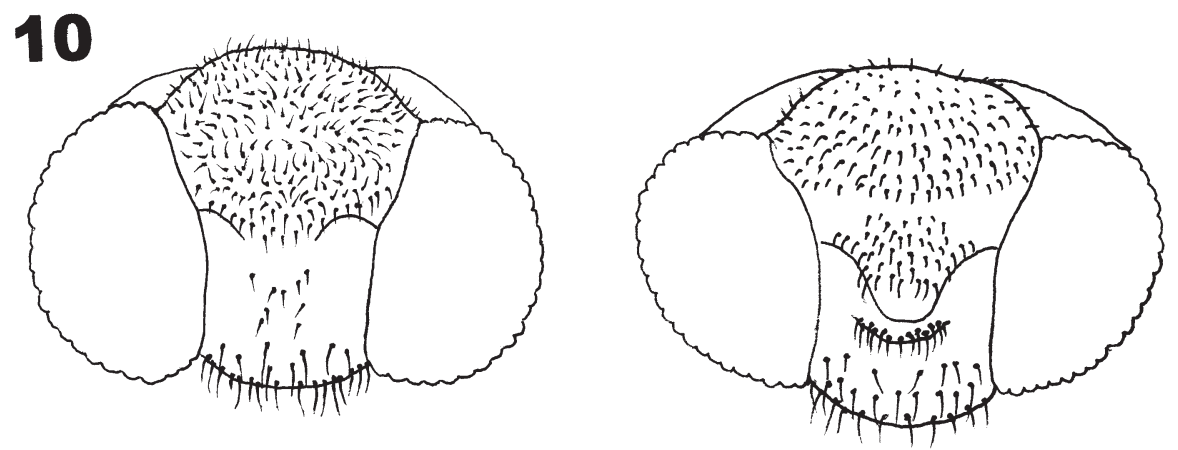

\section{2}

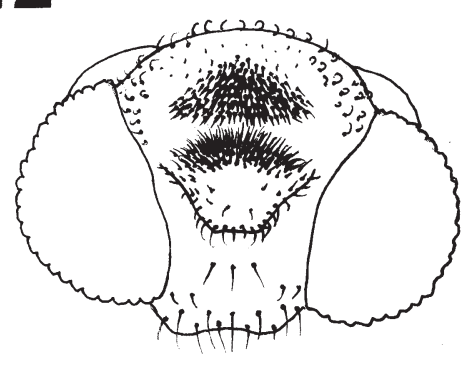

14
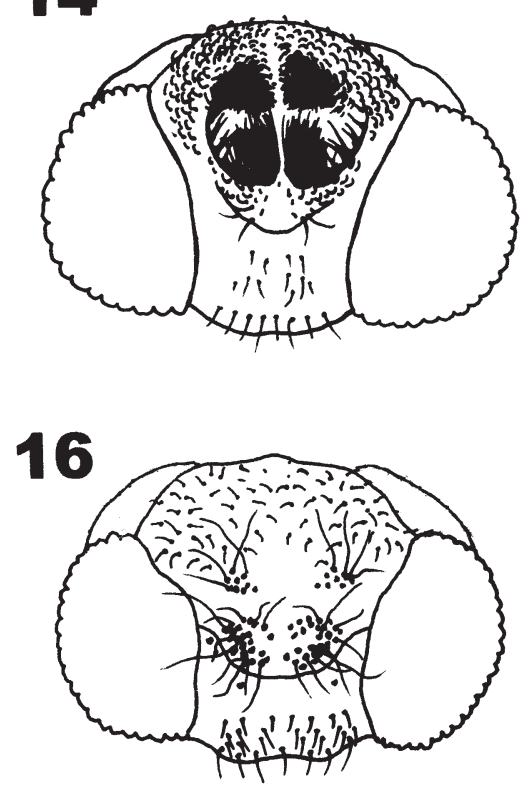

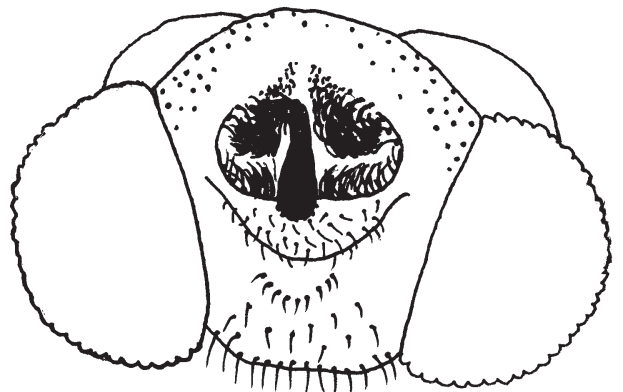

13

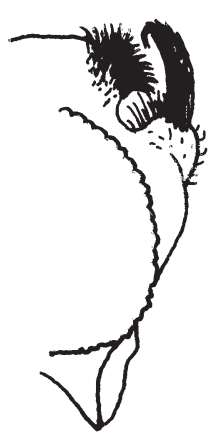

15

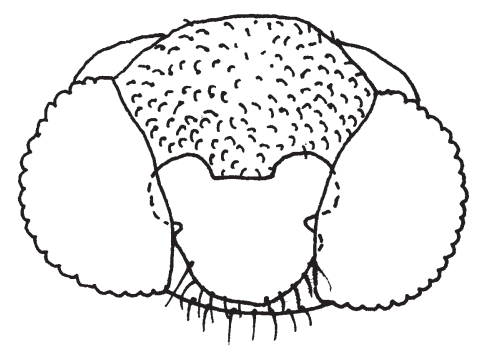

17

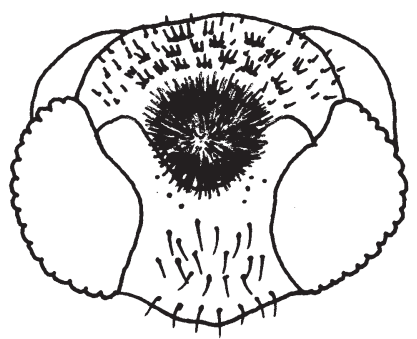

0,5

Figs. 10-17.- Male vertex in antero-dorsal view of Coniopteryx spp. 10: C. atlasensis. 11: C. stuckenbergi. 12: C. perisi. 13: C. canariensis n. sp. (also lateral view). 14: Coniopteryx sp. tentatively assigned to C. atlasensis. 15: C. kerzhneri. 16: Coniopteryx sp. tentatively assigned to C. verticicornis. 17: C. verticicornis. Scale in $\mathrm{mm}$.

Figs. 10-17.- Vista antero-dorsal del vértex masculino de Coniopteryx spp. 10: C. atlasensis. 11: C. stuckenbergi. 12: C. perisi. 13: C. canariensis n. sp. (también en vista lateral). 14: Coniopteryx sp. asignado tentativamente a C. atlasensis. 15: C. kerzhneri. 16: Coniopteryx sp. asignado tentativamente a C. verticicornis. 17: C. verticicornis. Escala en $\mathrm{mm}$. 
18

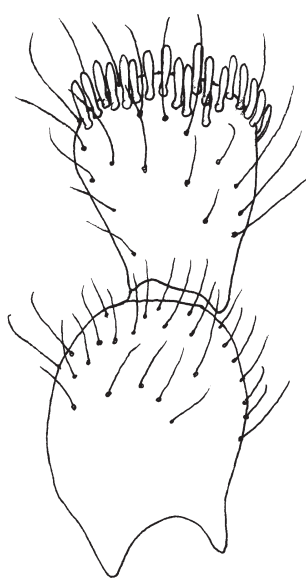

19

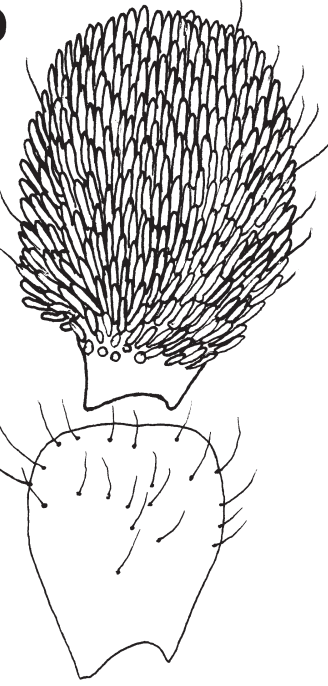

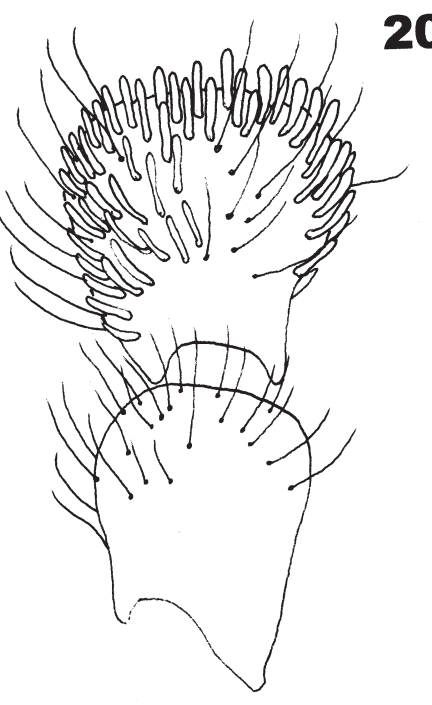

20

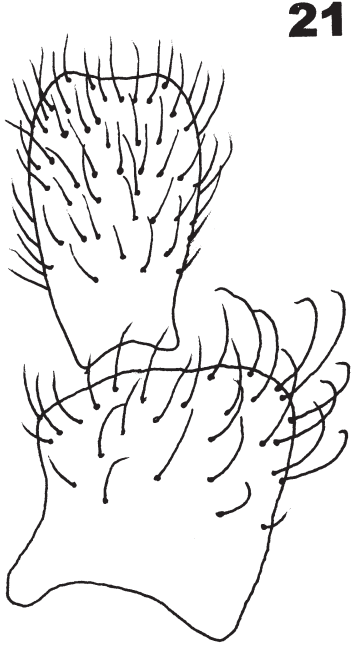

0,2

Figs. 18-20.- Male scapus and pedicel in dorsal view of Coniopteryx spp. 18: C. atlasensis. 19: C. perisi. 20: C. stuckenbergi. 21: C. canariensis $\mathrm{n}$. sp. Scale in $\mathrm{mm}$.

Figs. 18-20.- Escapo y pedicelo masculinos en vista dorsal de Coniopteryx spp. 18: C. atlasensis. 19: C. perisi. 20: C. stuckenbergi. 21: C. canariensis n. sp. Escala en mm.

nal segments and vertex are showed in figures 10, 18. Opposite other studied Moroccan specimens, and other S.E. Iberian specimens have a very different vertex (Fig. 14). Probably new studies will bring us new descriptions of new species, in these cases when a larger number of specimens will be collected and studied.

SPAIN: Almería, Antas, 9.VI.1994 $10^{7}$ on Tamarix gallica, L. Díaz Aranda (VM). Badajoz, Camino Encinas, Burguillos del Cerro, 14.VII.2001 $10^{7} *$ (h-Fig. 10, 18), 1 9 on Quercus rotundifolia, V.J. Monserrat (VM). Córdoba, Baena, 27.VIII.1994 $10^{7}, 2$ 우 우 at light, M. Baena (VM). Granada, La Herradura, 8.IX.2001 $10^{7} *$ (h-Fig. 14) at light, V.J. Monserrat (VM).

Coniopteryx (Xeroconiopteryx) loipetsederi Aspöck, 1963

Known from Southern Europe and Algeria, associated to thermic, sometime dry Mediterranean habitats. Imagos recorded on very different fanerophytous: (Olea, Tamarix, Juniperus, Ceratonia, Quercus, Pistacea, Myrtus, Acacia, Populus, Ulmus, Citrus \& Pinus), was commonly collected at light, who show its association with low vegetation (usually not adequately sampled).

SPAIN: Granada, La Herradura, 8.IX.2001 $30^{7} 0^{\pi}$ at light, V.J. Monserrat (VM). Segovia, Chañe, 18.V-3.VII.2000 $10^{7}$ at
Malaise traps in a strawberry field, J. Gómez (VM). Valencia, Quartell Font, 21.XI.2000 19 on Citrus reticulata, L. Alvis (VM).

Coniopteryx (Xeroconiopteryx) pinkeri Aspöck \& Aspöck, 1965

A scarcely known species, recorded from West Canary Islands on Laurus, Pinus, Erica and Spartocytisus.

SPAIN: Canary Islands, La Palma, P.N. de La Caldera de Taburiente, Barranco de Las Traves, (1,068 m), 23.VIII.1999 2 우 우 at Malaise Trap, T .Domingo (MNCN), 5.IX.1999 10", 1 을 at Malaise Trap, T. Domingo (MNCN), Playa de Taburiente (750 m), 20.XII.1999 $10^{\pi}$ at Malaise Trap, T. Domingo (VM).

Coniopteryx (Xeroconiopteryx) kerzhneri Meinander, 1971

Recorded from desertic and sub desertic habitats in Southern limits of West Palaearctic: Mongolia, Kazakhstan, Uzbekistan, N. Africa (Egypt, Algeria) and Europe (S.E of Spain). Frequently collected on Tamarix, also on Ceratonia, Arundo and Pinus.

SPAIN: Almería, Rambla Morales 11.VIII.1988 10 * (h), A.Baz (VM). Granada, Carboneras, Rambla Río Carboneras, 17.VIII.2001 $10^{7}$ on Tamarix gallica V.J.Monserrat (VM). 


\section{Coniopteryx (Xeroconiopteryx) perisi Monserrat, 1976}

Recorded from Mediterranean Spain and Morocco, frequently in xeric areas of Mediterranean influence, imagos on Pinus halepensis, Juniperus oxycedrus, Pistacea lentiscus, Quercus rotundifolia, also on Rosmarinus and Crataegus.

As it was mentioned, the presence-absence of scale like hairs in the male scapus is a very variable character. The recorded specimen has pedicel size, vertex and male genitalia characteristics of this species, but pedicel is cover with a lot of scale like hairs (Fig. 12, 19) never observed in other specimens (Monserrat, 1976, Aspöck et al., 1980).

SPAIN: Zaragoza, Pina de Ebro, 20.IX.1993 10* (h), 1 우 at light in a wood of Juniperus thurifera, J. Blasco (VM)

\section{Coniopteryx (Xeroconiopteryx) aequatoriana Monserrat,} 1989

Species known from Equatorial Guinea, and recorded on Elaeis guineensis, Poga oleosa and Theobroma cacao. The females currently assigned to this species do not have the lateral gonapophyses fused which is characteristic of the subgenus and which has already been mentioned by Monserrat (1989). Its pedicel is longer than the scape, a fact that is rather peculiar.

UGANDA*: Bundibugyo, Semliki Forest, $0^{\circ} 48^{\prime} \mathrm{N} 30^{\circ} 8^{\prime} \mathrm{E}$, 670 m, 5-12.II.1997 2 우 T. Wagner (VM) on Ficus capensis, 2 우 우 T. Wagner (VM) on Elaeis guineensis. Masindi, N Sonso, Budongo Forest, $1^{\circ} 45^{\prime} \mathrm{N} 31^{\circ} 35^{\prime} \mathrm{E}, 1,200 \mathrm{~m}, 19-$ 30.VI.1995 10, 1 우 T. Wagner (VM), on Cynometra alexandri, 11-20.VII.1995 10", 3 우 $\mathrm{T}$. Wagner (VM), on Tecla nobilis.

\section{Coniopteryx (Xeroconiopteryx) canariensis n. sp.}

TYPE: SPAIN: Tenerife, Las Cañadas, Cañada Blanca, (UTM 340.48, 3123.98), (2,110 m), 4.VII.1996 10" at Malaise Trap in a Descurainia bourgeanana bushs area, A.Camacho, (VM). PARATYPES: SPAIN: La Palma, Lomo del Caballo (2,180 m), 20.VIII.1991 $10^{7}$ on Juniperus cedrus, A. Baz (VM), Roque de los Muchachos, (UTM 28RBS2084-3), (2,250 m), 27.VII.2000 $10^{\pi}$ at Malaise Trap, A. Sánchez (MNCN), 31.VIII.2000 $10^{\pi}$ at Malaise Trap, T. Domingo (MNCN). Tenerife, Las Cañadas, Cañada Blanca, (UTM 34048, 3123.98), (2,110 m), 4.VII.1996 $2 \sigma^{7} \sigma^{7}, 1$ 웅 at Malaise Trap in a Descurainia bourgeauana bush area, A. Camacho (VM), Cruz de Tea, (UTM 333.13, 3126.39), (2,110 m), 29.VII.1996 $10^{\pi}$ at Malaise Trap in a Pterocephalus lasiospermus bush area, N. Zurita (VM), Roque del Peral, (UTM 345.07, 3130.7), (2,040 m), 29.VI.1996 $10^{\text {" }}$, $2 ㅇ$ at Malaise Trap in a Spartocytisus and Adenocarpus bushes area, M.Arechavaleta (VM).

DiAGNOSIS: A dark winged species with a triangle hole in male vertex covered with two setae formations and with a bristle of long setae on the middle anterior margin (Fig. 13). Antennae in males without scale like hairs, and scapus with a strong knob in the inner anterior angle (Fig. 21).

DESCRIPTION: A common morphology species with males bearing a triangle hole in vertex covered with two curved setae formations and with a bristle of long setae on the middle anterior margin (Fig. 13). Antennae in males without scale like hairs, scapus with a strong knob in the inner anterior angle (Fig. 21). Number of flagelomera: 29-31 in males $(\mathrm{n}=5)$ and 27 in females $(\mathrm{n}=3)$. Wings are very dark brown with lighter bands on RS-M and CU2-A1 in forewings, and $\mathrm{A} 1-\mathrm{A} 2$ in hind wings. Forewing's length of type: $1.87 \mathrm{~mm}$, of hind wing: $1.37 \mathrm{~mm}$. Male genitalia very similar and into the variability margin of C. atlasensis Meinander, 1963.

Discussion: The male genitalia is quite similar to those of C. atlasensis Meinander, 1963, as it is recorded in other species as C. perisi (Monserrat, 1976), although the shape and structures of male vertex (Fig. 10,13) and the inner prominent male scapus (Fig. 18, 21) differentiate both. It seems to be a very orophylous species $(2,040-2,250 \mathrm{~m})$ associated with low bush vegetation in open and sunny areas, where substitutes to other Coniopteryx species in higher cotes. The specimen recorded as $C$. atlasensis Meinander, 1963, in La Palma at 2,180 m (Monserrat, 1995) belongs to this new species.

Coniopteryx (Coniopteryx) parthenia (Navás \& Marcet, 1910) sensu Meinander, 1972

A west Palaearctic species strongly associated to coniferous plants.

SPAIN: Almería, El Marchal, 10.VI.1994 10 L L. Díaz Aranda (VM). Murcia, Alhama de Murcia, 8.VI.1994 10", 2 우 우 L. Díaz Aranda (VM), Atamaría, 13.V.1994 30 $0^{\prime \prime}$, 4 우 우, 8.VI.1994 $50^{x} 0^{x}$, 3 우 우, 12.VII.1994 10", L. Díaz Aranda (VM), Calblanque, 13.V.1994 10", 1 ㅇ L. Díaz Aranda (VM), Gebas, 7.VI.1994 10", 2 우 L. Díaz Aranda (VM), Sucina, 10.V.1994 10 2 , 2 우 우 L. Díaz Aranda (VM), Torrepacheco, 10.V.1994 20 $0^{7} 0^{7}, 6$ 우 우 L. Díaz Aranda (VM). Zaragoza, Pina de Ebro, very abundant material (specially females) collected between VI-IX.1993, J. Blasco (VM), these one at light in a wood of Juniperus thurifera, others in Pinus halepensis (25 ex.), Tamarix gallica (3 ex.), Tetraclinis articulata (3 ex.) and Quercus ilex (1 ex.).

\section{Coniopteryx (Coniopteryx) borealis Tjeder, 1930}

Known from Europe, Morocco and Tunisia. Usually recorded on deciduous (Quercus, Crataegus, Carpinus, Citrus, Corylus, Populus, Betula, Alnus, Castanea, Ulmus, Ceratonia, Pistacea, Acacia, Fraxinus, Olea), also on riverside vegetation, and scarcely on coniferous (Pinus, Juniperus). A very euryoic species. 
SPAIN: Murcia, Atamaría, 8.VI.1994 20" $0^{7}$ on Pinus halepensis, L. Díaz Aranda (VM). Valencia, Alberic, 3.XII.1997 $10^{7} \mathrm{~J}$. López (VM) this data demonstrates that the species over winter as imago.

\section{Coniopteryx (Coniopteryx) ezequi Monserrat, 1984}

Known from East half of Iberia Peninsula. It was probably misdated in Bioko Island from Equatorial Guinea by Monserrat (1995) and recorded in August on arboreal near harbour, or it has really been accidentally introduced probably from Spain by man. Strongly associated to Juniperus, also scarcely collected on Pinus, and also at light. Very stenotopic, and local, but very abundant and easy to see flying at sunset around Juniperus.

SPAIN: Zaragoza, Pina de Ebro, abundant material collected between III-IX.1993, 1994 on Juniperus thurifera, or at light in a wood of this plant species, J. Blasco (VM).

\section{Coniopteryx (Holoconiopteryx) haematica McLachlan, 1868}

A species known from Europe, mostly in Central and South Europe, also from N. Africa (Morocco and Algeria), N. Turkey and Cyprus, with a marked association with sclerophyllous Quercus. Also recorded on Populus, Crataegus, Ceratonia, Pistacea, Citrus, Olea, Carpinus \& Prunus. Scarcelly on coniferous (Juniperus \& Pinus). Sometime emerged from oak-gall of Andricus kollari (Htg.).

SPAIN: Menorca*, Ciutadella N., 22.V.1998 $20^{\pi} 0^{\pi}$ D. Ventura, Sant Climent, 29.IX.1997 2 우 D. Ventura, 26.V.1998 $10^{7}$ D. Ventura, Torret 24.IX.1997 10 D. Ventura (VM).

Coniopteryx (Holoconiopteryx) drammonti Rousset, 1964

Known from South Europe, Morocco, Turkey, and Georgia. Usually collected on Quercus, also on Juniperus, Fagus, Acer, Crataegus, Pinus and Carpinus.

SPAIN: Castellón, Jerica, 31.VII.2001 10" on Celtis australis, V.J. Monserrat (VM).

\section{Coniopteryx (Holoconiopteryx) verticicornis Mon- serrat, 1989}

Species recorded from Equatorial Guinea on Elaeis guineensis, whose previously known distribution is notably enlarged. The specimens from Uganda agree well with original description, however specimens from Mozambique do not exactly agree with those contributed by Monserrat (1989) because the incision of the hypandrium is deeper, and the caudal shape of the parameres is less cur- ved. Also the vertex morphology of male is quite different (Fig. 16) from usual (Fig. 17).

MOZAMBIQUE*: I.Inhaca, 25-26.VIII.1999, $20^{7} \sigma^{7} *(\mathrm{~h}), 1$ ㅇ V.J. Monserrat at light (VM). UGANDA*: Masindi, N Sonso, Budongo Forest, $1^{\circ} 45^{\prime} \mathrm{N} 31^{\circ} 35^{\prime} \mathrm{E}, 1.200 \mathrm{~m}, 19-30 . \mathrm{VI} .1995$ $50^{7} 0^{7 *} *(\mathrm{~h}), 5$ 우 우 T. Wagner (VM), 9 on Cynometra alexandri and 1 on Trichilia rubescens.

Coniopteryx (Metaconiopteryx) esbenpeterseni Tjeder, 1930

Known from Europe, Anatolia, Armenia, Aserbeidshan and Ukraine. Usually on deciduous (Corylus, Quercus, Ulmus, Prunus, Ilex, Salix, Tamarix, Carpinus, Acer, Fagus, Crataegus, Betula, Hedera \& Tilia), also on riverside vegetation and scarcely on coniferous (Pinus \& Picea). Usually on wet habitats - microhabitats, even in more or less xeric places.

SPAIN: Castellón, Jerica, 31.VII.2001 10" on Celtis australis, V.J. Monserrat (VM).

Coniopteryx (Metaconiopteryx) tjederi Kimmins, 1934

A species known from Central and South Europe, Morocco, Asia Minor and Ukraine. Very euryoic. Recorded on arboreal vegetation, usually on deciduous (Corylus, Quercus, Ulmus, Prunus, Ceratonia, Pistacea, Salix, Populus, Alnus, Tamarix, Fraxinus, Arundo, Sarothamnus, Crataegus \& Juglans), also on riverside vegetation, leguminous and scarcely on coniferous (Pinus \& Juniperus). Usually on wet habitats - microhabitats, even in more or less xeric Mediterranean places.

SPAIN: Almería, Antas, 9.VI.1994 200 $0^{\pi}, 2$ 우 $ᄋ$ on Tamarix gallica, L. Díaz Aranda (VM), Llano Don Antonio, 9.VI.1994 $10^{\prime}, 1$ o on Tamarix gallica, L. Díaz Aranda (VM).

\section{Coniopteryx (Metaconiopteryx) arcuata Kis, 1965}

Known from Europe, Morocco and Turkey in wet woody Mediterranean - influence habitats, recorded on Quercus, Fagus, Crataegus, Alnus, Acer, Corylus, Ulmus, Pyrus, Acacia, \& Carpinus, also very scarcely on coniferous (Pinus).

SPAIN: Castellón, Jerica, 31.VII.2001 $10^{7}$ on Celtis australis, V.J. Monserrat (VM).

\section{Parasemidalis fuscipennis (Reuter, 1894)}

An Holarctic species known from Europe, extended to Ukraine and Mongolia. Also recorded from USA, and Mexico. Historically associated with Coniferous (Pinus and Juniperus), although some specimens have been recorded on deciduous (Quercus robur, Q. rotundifolia, Q. faginea, Carpinus, Olea europaea \& Crataegus monogyna), 
some on riverside vegetation and Typha and frequently in parks, too.

ITALY*: Toscana, Livorno, Isola di Capraia, 24.VI.1993 10" Butanelli (VM). SPAIN: Pina de Ebro, Fuente del Noble, 30.I.1993 1 우 (probably over wintering) on Krascheninnikovia ceratoides, J. Blasco (VM).

\section{Parasemidalis alluaudina (Navás, 1912)}

This species was considered to be endemic to Las Cañadas in Tenerife (Ohm 1963), even it was later cited from other localities including Gran Canaria and La Palma Islands.

The differences between this species and other Canary Island species of this genus ( $P$. fusca Meinander, 1963 described from Morocco, and later recorded from Gran Canaria and Tenerife) in particular, are very slight. Meinander $(1963,1972)$ and Ohm (1963) cite some characteristics of little taxonomic value as distinguishing. For example they noted differences in the wing-span, (the length of $P$. alluaudina fore-wings being generally greater than $3.50 \mathrm{~mm}$, and those of $P$. fusca generally less than $3.50 \mathrm{~mm}$ ); the coloration of the wing membrane-greyish in $P$. alluaudina and dark brown, almost black in P. fusca. They also cited differences in the number of antennal segments (41-48) in P. alluaudina, (42-46) in P. fusca, as well as differences in the male genitalia such as the relation of the length of the style to that of the base of the gonarcus and the presence or absence of the caudal expansion of the hypandrium.

Through examination of abundant material collected in Las Cañadas we can conclude that none of these distinguishing characters are valid. The length of the fore wings in $P$. alluaudina is highly variable in males as well as in females. And so we find in the cited bibliography $(3.10-4.70 \mathrm{~mm})$ and in the data currently noted over 15 specimens whose fore wing measurements in males are: 3.85 , $4.05,4.35,4.60 \mathrm{~mm}$ and in females: $2.90,2.95$, $3.10,3.20,3.25,3.65,3.65,3.80,3.80,3.90,3.90$ $\mathrm{mm}$, thus overlapping data from $P$. alluaudina which was cited as differential with $P$. fusca (2.90$3.50 \mathrm{~mm}$ ) rendering it is no longer valid. The species currently examined have an enormous variability in the wing pigmentation, with pale specimens, pale ones with the venation highlighted with brown, brown ones with a stripe between SR and $\mathrm{M}$, brown ones with a stripe between SR and M and another between $\mathrm{M}$ and $\mathrm{CU}$, uniformly brown ones, and dark brown, almost black ones. This character does not seem valid either for separation of the two species. It is known that melanism is a character which appears as an adaptation to altitude and for this reason tends to be more pronounced in specimens which population lives in more elevated environments resulting in great variability. However, among the specimens collected in Las Cañadas, and in addition to the cited general variability, there is a tendency for the males to be almost always paler than the females which perhaps points out to the connection with the colour and the age of a specimen. Females are more long-lived and achieve a more apparent melanism, which involves a wide gamut of intermediate melanic phases. We conclude that this character is not valid either for differentiating the two species.

The number of antennal segments is a rather inconsistent character in this genus and its overlapping between the two species renders it insignificant in this case. The male specimens now studied had $45,47,49,50$ segments in the flagellum, and the females $-38,39,40,40,41,41,41,41,42,42$, 42 which makes its variability even greater. Finally the variability that was observed in the length of the style of these specimens in respect to the gonarcus is very greatly, and the caudal process of the hypandrium is slightly dilated in some of the currently studied specimens, as is mentioned for $P$. fusca. In light of all the above, a new synonymy which was already suspected by Monserrat \& Díaz-Aranda (1990) is proposed:

Parasemidalis alluaudina (Navás, 1912)

= (Semidalis alluaudina Navás, 1912: 749)

$=($ Parasemidalis fusca Meinander, 1963: 105) n. syn.

Specimens cited by Klingstedt (1936) as P. fuscipennis (Reuter, 1894) from Tenerife (Las Cañadas) belong to this species. P. fuscipennis should be discarded from Canary fauna (Ohm, 1963, Meinander, 1965, 1972), and the female cited by Meinander (1965) from: Lanzarote, Ayiza was assigned to $P$. similis Ohm, 1986 when Ohm (1986) described it.

SPAIN: Canary Islands, Tenerife, Las Cañadas, 30.VI.1995 1 우, 1 우 A. Camacho, V.1996 40" $0^{\prime \prime}, 24$ 우 우, VI.1996 40" $0^{\prime \prime}$, 7 우 우, VII.1996 $50^{7} 0^{7}, 3$ 우 우, VIII.1996 10", X.1996 1 우 P. Oromí, N. Zurita, M. Arechavaleta and A. Camacho (DZUL, VM), Parador del Teide $(2,000 \mathrm{~m})$ 15.VII.1966 $10^{\prime \prime}$ K.Guichard \& P.Ward (VM). This material seems to favour monovoltine character in this species and the probability that the females hibernate.

\section{Conwentziini Enderlein, 1905}

Hemisemidalis pallida (Withycombe, 1924)

Species known from xeric Southern limits of West Palaearctic, from Mongolia to Morocco. Associated to dry areas, usually recorded on desert plants and xerophiles threes of Mediterranean 
influence (Tamarix, Haloxylon, Nerium, Pistacea, Tetraclinis, Caragana, Olea, Acacia), also on Pinus, Quercus \& Eucaliptus and herbaceous Lasiagrostis \& Ephedra. But it is strongly associated to Juniperus spp., where the most of specimens collected have been found.

SPAIN: Almería, Embalse de Níjar, 8.VII.1996 1 우 on Tamarix gallica, V.J. Monserrat (VM). Córdoba, Baena, 23.VI.1994 $10^{7}$ M. Baena (VM), 28.VIII.1994 10 $10^{7}$ M. Baena (VM). Granada, La Herradura, 8.IX.2001 10", 1 우 at light, V.J. Monserrat (VM). Murcia, Calblanque, 12.VII.1994 10" on Pinus halepensis, L. Díaz Aranda (VM). Zaragoza, Pina de Ebro, abundant material collected between V-VIII.1993, 1994 at light in a Juniperus thurifera wood, and from galbuli of Juniperus thurifera, J.Blasco (VM).

\section{Conwentzia psociformis (Curtis, 1834)}

An Holarctic species extended by man to Canada, USA and New Zealand. Usually collected on deciduous trees.

SPAIN: Badajoz, Camino Encinas, Burguillos del Cerro, 14.VII.2001 1 ㅇ on Quercus rotundifolia, V.J. Monserrat (VM). Jaén, Torredelcampo, 12.X.1996 $10^{7}$ on Hedera helix, V.J. Monserrat (VM). Murcia, Casas de Pedro, 8.VI.1994 $10^{\circ}$ on Olea europaea, V.J. Monserrat (VM). Valencia, Cheste, 29.XI.2000 $4 \sigma^{7} \sigma^{\prime \prime}$ on Citrus reticulata, L. Alvis (ETV), Godella, 20.XII.2000 3 우 우 on Citrus sinensis, L. Alvis (ETV).

\section{Conwentzia pineticola Enderlein, 1905}

An Holarctic species extended by man to Canada and USA. Usually recorded on coniferous trees.

SPAIN: La Herradura, 23.IX.2000 $10^{7}$ on Pinus halepensis, V.J. Monserrat (VM). Madrid, Montarco, 25.VI.1994 $10^{7}$ J. López (VM). Murcia, Alamaria, 13.V.1994 10" on Pinus halepensis, L.Díaz Aranda (VM).

\section{Semidalis aleyrodiformis (Stephens, 1836)}

A west Palaearctic species, expanded to S. Asia and usually associated with arboreal habitats, deciduous or coniferous, recorded on Abies, Pinus, Juniperus, Populus, Corylus, Fagus, Quercus, Crataegus, Carpinus, Ulmus, Prunus, Ceratonia, Citrus, Acacia, Ilex, Pistacea, Buxus, Arbutus, Olea, Taxus, Arundo, etc. One of the most euryoic coniopterygid species, living from wet woody subalpine habitats to desertic and sub-desertic areas, on a wide plant substrates.

SPAIN: Almería, Embalse de Níjar, 9.VI.1994 1 ㅇ L. Díaz Aranda (VM), Fuente de la Higuera, 9.VI.1994 50" $0^{7}, 6$ 우 우 V.J. Monserrat (VM), Mojácar, 9.VI.1994 20 $0^{7}, 1$ 우 L. Díaz Aranda (VM). Castellón, Jerica, 31.VII.2001 10', V.J. Monserrat (VM). Córdoba, Baena, 27.VIII.1994 $10^{7}$ M. Baena (VM). Murcia, Campo López, 12.VII.1994 30 $30^{\pi}, 1$ 으, L.

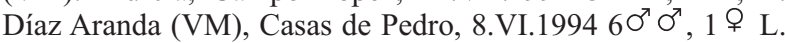

Díaz Aranda (VM), La Hurona, 13.VII.1994 20 $0^{\pi}, 1$ ㅇ L. Díaz Aranda (VM), Rambla Chuecos, 8.VI.1994 10", L. Díaz Aranda (VM), Rambla Minaros, 8.VI.1994 10", 2 우 우 L. Díaz Aranda (VM), 12.VII.1994 20" $0^{\circ}, 1$ ㅇ L. Díaz Aranda (VM), Torrepacheco, 14.VII.1994 40" $\sigma^{\prime \prime}, 1$ ㅇ L. Díaz Aranda (VM). Valencia, Carlet, 23.VIII.2001 40" $\sigma^{\circ}, 1$ 우 on Citrus sinensis, L. Alvis (ETV), Godella, 20.XII.2000 a third instars larva on Citrus sinensis, L. Alvis (VM), Quartell Font, 21.XI.2000 $80^{\top} 0^{\top}, 10 \%$ $\odot$ and 4 third instars larvae on Citrus reticulata, L. Alvis (ETV, VM). The other material 21 specimens were collected on Olea europaea, 11 on Zizyphus lotus, 5 on Pinus halepensis, 3 on Nerium oleander, 2 on Pistacea lentiscus, 1 on Ceratonia siliqua, 1 on Celtis australis and 1 at light.

\section{Semidalis vicina (Hagen, 1861)}

A species known from Southern of Europe, Morocco, Algeria and Central and East of North America. Associated to thermic and dry (but not desertic or sub-desertic) areas with Mediterranean climatic conditions, and collected on a wide range of trees without any special marked preference (Juniperus, Castanea, sclerophilous Quercus spp., Pistacea, Tamarix, Ceratonia, Olea, Mirtus, Acer, Citrus, etc.), probably living also / or on low vegetation.

SPAIN: Gerona, Rosas, Cala Murtra, 11.VIII.2001 1 우 on Quercus coccifera, V.J. Monserrat (VM).

\section{Semidalis africana Enderlein, 1906}

Species known from Kenya, Tanzania and South Africa of unknown Biology, whose variability has lead out to several synonymies and doubts in respect to the validity of the species later described (Meinander, 1990, 1998). The specimens now cited have parameres identical to that cited by Meinander (1990); nevertheless, the caudal process on the posterior margin of the hypandrium is not truncated, but rather bifurcated, a fact that enlarges the known variability of this species (Meinander, 1998b).

UGANDA*: Masindi, Sonso, Budongo Forest, $1^{\circ} 45^{\prime} \mathrm{N} 31^{\circ}$ 35'E, $1.200 \mathrm{~m}, 19-30 . V I .199520^{7} 0^{7} \mathrm{~T}$. Wagner (VM), on Cynometra alexandri (VM).

\section{Semidalis fuelleborni Enderlein, 1906}

Species known from Angola, South Africa, Namibia, Botswana and Tanzania of unknown biology. The $\sigma^{7} \sigma^{7}$ specimens now studied have a different grade of sclerification in the dorsal membranous zone of the paramera, making it seems as if a slight tooth with a different angle of inclination in respect to the caudal tooth exists. This character does not seem sufficient to uphold the validity of other close species as S. africana Enderlein, 1906 making very difficult their separation, and in particular S. deemingi Meinander, 1975, described from 
Nigeria on the basis of one single specimen and probably belong to the same species.

UGANDA*: Bundibugyo, Semliki Forest, $0^{\circ} 48^{\prime}$ N 30 8'E, 670 m, 5-12.II.1997 50 $\sigma^{7}, 2$ 우 우 T. Wagner (VM) 4 specimens on Ficus capensis and 3 on Elaeis guineensis. Masindi, N Sonso, Budongo Forest, $1^{\circ} 45^{\prime} \mathrm{N} 31^{\circ} 35^{\prime} \mathrm{E}, 1.200 \mathrm{~m}, 19-30 . \mathrm{VI} .1995$ $120^{7} \sigma^{\prime \prime}, 11$ ㅇ ㅇ T. Wagner (VM), on Cynometra alexandri, 2130.VII.1995 $10^{7}$ T. Wagner (VM), on Rinorea ardisiifolia, $10^{7}$, 1 T T. Wagner (VM), on Tecla nobilis, 15-25.I.1997 $20^{7} \sigma^{7}$, $20^{\top} \sigma^{\top}, 4$ 우 우 T. Wagner (VM), on Rinorea beniensis.

\section{Semidalis candida Navás, 1916}

Species known from the Canaries, Madeira, and South of Morocco, usually associated to Pinus and Cupresus, but also recorded on Withania, Ploclama, Acacia, Myrica, Laurus, Euphorbia, Tamarix \& Prunus.

SPAIN: Canary Islans, La Palma, P.N. de La Caldera de Taburiente, Barranco de Las Traves, 3.VIII.1999 2 우 at Malaise Trap, T. Domingo (MNCN), $10^{7}$ at Yellow Trap, T. Domingo (MNCN), 10.VIII.1999 2 우 우 at Malaise Trap, T. Domingo (MNCN), 23.VIII.1999 $3 \circ \circ$ 우 at Malaise Trap, T. Domingo (MNCN), 5.IX.1999 $2 \%$ 우 at Malaise Trap, T. Domingo (MNCN), 20.IX.1999 1 ㅇ at Malaise Trap, T. Domingo (MNCN), 22.IX.1999 $20^{7} \sigma^{7}$ at Yellow Trap, T. Domingo (MNCN), Lomo de Las Chozas, 17.XI.1999 1 ㅇ at Malaise Trap, T. Domingo (MNCN), Roque de la Cumbrecita, 12.VIII.1999 $210^{\pi} \sigma^{\pi}, 34 \uparrow \varnothing$ at Malaise Trap, T. Domingo (MNCN), 25.VIII.1999 1 우 at Yellow Trap, T. Domingo (MNCN), 22.IX.1999 1 운 at Yellow Trap, T. Domingo (MNCN), Roque de los Muchachos, 31.VIII.2000 1 \% at Malaise Trap, T. Domingo (MNCN). Tenerife, Las Cañadas, 23.IX.1995 1 \% A. Camacho (DZUL), 1.V.1996 1ㅇ A. Camacho (DZUL), 17.V.1996 3 우 우 A. Camacho (VM), 29.VII.1996 20" $0^{7}, 1$ 우 N. Zurita (DZUL).

\section{Semidalis pluriramosa (Karny, 1924)}

A circum-saharian species known from Egypt, Algeria, Sudan, Nigeria, Morocco, Tunisia and extended to the SE of the Iberian Peninsula and Yemen. Recorded on dry areas on Eucalyptus, Citrus, Phoenix, Olea, Ceratonia, Amygdalus, Acacia, Zizyphus, Tamarix, Arundo and Tetraclinis. MALI*: Bandiagara, 18.VII.1997 2 우 ․J. Monserrat (VM). Douna, Zinzana, 16.VII.1997 $20^{\pi} \sigma^{\pi}$ V.J. Monserrat (VM). Promani, S. Djenné, 17.VII.1997 10 $0^{7}$ V.J. Monserrat (VM). Soke, E. Bla, 16.VII.1997, $3 \sigma^{7} \sigma^{7}$ V.J. Monserrat (VM). Somo, E. of San, 16.VII.1997 10 , 1 ㅇ V.J. Monserrat (VM). Of them, 5 specimens collected on Dicrostochys glomerata, 2 on Baissea multiflora, 2 on Vitellama panadara and 1 on Combretum micranthum.

\section{Semidalis mascarenica Fraser, 1952}

Species known from Madagascar, Reunion, Comoros and Seychelles with unknown biology. REUNION ISLAND: Hauts du Tampon, 15.IX.1997 70 $0^{7}$, 9 우 우 on Acacia mernsii, S. Quilici (VM).

\section{Semidalis pseudouncinata Meinander, 1963}

An Holomediterranean species known from Central and South Europe and North West Africa. Usually associated to coniferous: Cupresus, Thuja, Pinus, Cedrus, but very specially to Juniperus spp., also sometime recorded on Tetraclinis, Rosmarinus, Eucalyptus, Quercus, Pistacea \& Tamarix.

SPAIN: Granada, La Herradura, 8.IX.2001 10", 1 ㅇ at light, V.J. Monserrat (VM). Murcia, Atamaría, 12.VII.1994 40 $0^{\circ} 0^{7}$, 899 on Tetraclinis articulata, L. Díaz Aranda (VM), Succina, 10.V.1994 10" on Pinus halepensis, L.Díaz Aranda (VM).

\section{Semidalis teneriffae Meinander, 1972}

Species from the West Canary Islands recorded from laurel forest (Myrica, Erica and Laurus).

SPAIN: Canaries, Tenerife, Ruigómez, 2.IX.1995 $30^{\pi} 0^{\pi}$, 3 우 우 V.J. Monserrat (VM) on Laurus azoricus and Viburnum tinus ssp. rigidum.

\section{Semidalis guineana Monserrat, 1989}

Species known from Equatorial Guinea and recorded on wet wood and Eleais guineensis, who's currently known distribution, is now significantly expanded. The level of development of its terminal teeth of the parameres in some specimens is variable. In some specimens they become two well developed teeth, both curved upward and forward, one dorsal and one caudal (Fig. 30), and not just one dorsal tooth as Monserrat, 1989 indicates. The specimens had abundant arthropod remains in their peritrophic membranes.

UGANDA*: Bundibugyo, Semliki Forest, $0^{\circ} 48^{\prime} \mathrm{N} 30^{\circ}$ 8'E, 670 m, 5-12.II.1997 10" T. Wagner (VM) on Ficus capensis. Masindi District, N Sonso, Budongo Forest, $1^{\circ} 45^{\prime} \mathrm{N} 31^{\circ} 35^{\prime} \mathrm{E}$, 21-30.VII.1995 $50^{\text {T }} 0^{\text {T } *, 6} 6$ 우 우 T. Wagner (VM), 15-25.I.1997 $20^{7} 0^{7}, 5$ 우 우 T. Wagner (VM), 11 specimens collected on Cynometra alexandri, 3 on Rinorea beniensis, 2 on Trichilia rubescens and 2 on Tecla nobilis.

\section{Semidalis pallidicornis n. sp.}

TYPE: UGANDA: Masindi District, $\mathrm{N}$ Sonso, Budongo Forest, $1^{\circ} 45^{\prime} \mathrm{N} \mathrm{31} 1^{\circ} 35^{\prime} \mathrm{E},(1.200 \mathrm{~m}), 1-10$. VII.1995 $10^{7}$ on Trichilia rubescens, T. Wagner (VM).

PARATYPES: UGANDA: Bundibugyo, Semliki Forest, $0^{\circ} 48^{\prime}$ $\mathrm{N} 30^{\circ}$ 8'E, $^{\prime}(670 \mathrm{~m}), 5-12 . \mathrm{II} .19971$ ㅇ T. Wagner (VM) on Ficus capensis. Masindi District, N Sonso, Budongo Forest, $1^{\circ} 45^{\prime} \mathrm{N}$ $31^{\circ} 35^{\prime} \mathrm{E},(1.200 \mathrm{~m}), 19-30 . V I .199540^{7} \sigma^{7}, 11-20 . V I I .1995$ $40^{7} \sigma^{7}$ T. Wagner (VM), 5-15.I.1997 10", 4 우 우 T. Wagner (VM), 15-25.I.1997 20" $\sigma^{\pi}, 6$ 우 우 T. Wagner (VM), 13 specimens collected on Rinorea beniensis, 4 on Rinorea ardisiifolia, 3 on Cynometra alexandri and 1 on Trichilia rubescens.

Diagnosis: Species with a globose non sclerotized formation in the frontal region (Fig. 22, 23) and brown antennae, except for the last 5-6 flagellome- 


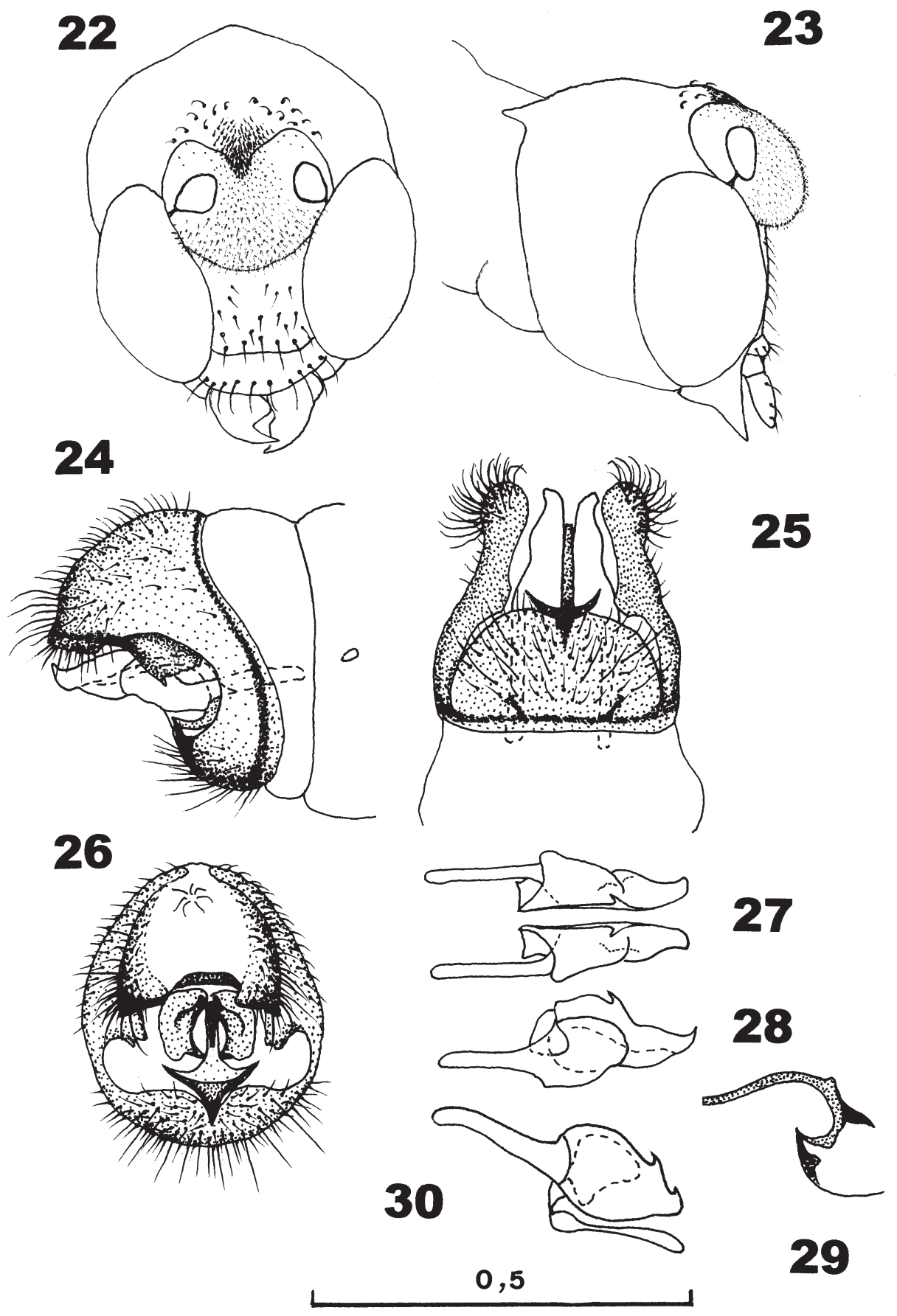

Figs. 22-29.- Semidalis pallidicornis n. sp. O'. 22: Scheme of head, anterior. 23: Ditto, lateral. 24: Abdominal apex, lateral. 25: Ditto, ventral. 26: Ditto, caudal. 27: Parameres, dorsal. 28: Ditto, lateral. 29: Penis, lateral. 30: Parameres of S. guineana from Uganda, lateral. Scale in $\mathrm{mm}$.

Figs. 22-29.- Semidalis pallidicornis n. sp. $0^{7}$. 22: Esquema de la cabeza, anterior. 23: Ditto, lateral. 24: Ápice abdominal, lateral. 25: Ditto, ventral. 26: Ditto, caudal. 27: Parámeros, dorsal. 28: Ditto, lateral. 29: Pene, lateral. 30: Parámeros of S. guineana de Uganda, lateral. Escala en mm. 
ra which are yellowish and pale. Male genitalia with a triangular formation in the caudal margin of the hypandrium (Fig. 24, 26) associated with a well differentiated and sclerotized penis (Fig. 25, 26), and with robust parameres which have a dorsal tooth (Fig. 27, 28).

DESCRIPTION: Head with a elongate vertex with a triangular formation with many microtrichia (Fig. $22,23)$, the frontal area is not sclerotized, protruding interiorly from the cephalic capsule (Fig. 22, 23). The scapus is inserted in this membranous zone and only joined to the cephalic capsule by a narrow lateral-extreme line of contact which is normally sclerotized (Fig. 22, 23). The scape is somehow longer than wider, sub-cylindrical in dorsal view, fusiform in lateral view. The pedicel is fusiform, and with almost double the length compared to the width. The flagelomera are 28-29 in number, the most basal ones being square and slightly more elongate than the more distal ones; they have two rings of setae. The antennae are dark brown and the 5-6 last flagelomera are pale yellowish. The labial and maxillary palpi are normal.

Wings with brown membrane, lighter around the margin and on both sides of the venation, especially on $\mathrm{M}$ and between $\mathrm{CU}_{2}-\mathrm{A}_{1}$. The length of the fore wings is $3.00-3.25 \mathrm{~mm}$, the length of the hind wings $-2.35-2.40 \mathrm{~mm}$.

The male genitalia with an ectoproct that bears caudal processes which are sub triangular in lateral view, and digit-form in ventral view (Fig. 24-26). They posses a wide internal process by way of incipient style (Fig. 26) and an anterior complete apodeme (Fig. 24). The hypandrium is relatively slender, semicircular. Its caudal margin elongates into a middle highly sclerotized sub triangular process which sharpens laterally and which serves as a base for the penis (Fig. 24-26, 29). The parameres are globose and robust, their inner margin is sub parallel with a caudal process which is curved upward, and a dorsal tooth (Fig. 27, 28). Uncini are absent. The penis is situated between the parameres, it is robust, sinuous and bears a conical anterior apodeme (Fig. 24-26, 29). Above the parameres, there is a double sclerite, probably the remains of the Xth sternite. It is well sclerotized, pigmented (Fig. 26) and heart-shaped in dorsal view.

The $P$ is unknown at the moment. Along with the cited males, numerous $q 9$ of the genus Semidalis were collected. However, the assignment of these specimens to this species or to the $S$. guineana, of similar external characteristics, it becomes problematic and subjective.
Aside from the biological data listed in regards to the type material, the presence of abundant arthropod remains in the peritrophic membranes of the mentioned specimens should be noticed.

Discussion: When it comes to the external morphology of S. pallidicornis n. sp., and the pigmentation of the antennae in particular: there are many Afro-tropical species of this genus with the last flagellomera darker, or the opposite (as demonstrated in this species). This type of pigmentation has been noted in S. mascarenica, $S$. deemingi y S. guineana (Meinander, 1972, 1974, 1975a, 1998b, Monserrat, 1989). However, the male genitalia of this new species is absolutely different because most of the Semidalis species of the area bear uncini beside to parameres (Meinander, 1972, $1983,1998 b)$. It seems to be a species close to $S$. maculipennis Meinander, 1975 of South Africa, and S. obscura Sziráki \& Greve, 1996 of Tanzania, given the existence of the caudal projection of the hypandrium (Fig. 24-26). However, in these species this projection is very different, the ectoprocts are also very different, the parameres have two or three dorsal teeth, and such a well differentiated and sclerotized penis does not exist (Meinander, 1983, 1998b, Sziráki \& Greve, 1996).

The pale pigmentation at the antennal ends is the characteristic that was chosen for its specific naming.

\section{ACKNOWLEDGES}

I wish to express my grateful thanks to the Institutions who allowed me to study the recorded material and to Teófilo Gómez-Calcerrada for reading the English manuscript.

\section{References}

Aspöck, H., Aspöck, U. \& Hölzel, H., 1980. Die Neuropteren Europas. Goecke \& Evers. Krefeld. t. 1: 495 pp. t. 2: 355 pp.

Aspöck, H. \& Hölzel, H., 1996. The Neuropteroidea of North Africa, Mediterranean Asia and of Europe: a comparative review (Insecta). In: Proceedings of the Fifth International Symposium on Neuropterology. Toulouse: 31-86.

AsPÖCK, H., HÖLZEL, H. \& ASPÖCK, U., 2001. Kommentierter Katalog der Neuropterida (Insecta: Raphidioptera, Megaloptera, Neuroptera) der Westpaläarktis. Denisia. Linz. 606 pp.

Carpenter, F. \& Lestage, J.A., 1928. Une sous-famille nouvelle (Fontenelleinae) du groupe des Conioptery- 
goidea Till. Université de Bruxelles Recueil Institut Zoologique Torley-Rousseau, 1: 153-172.

ENDERLEIN, G., 1914. Ueber zwei neue afrikanische Coniopterygiden. Bolettino del Laboratorio di Entomologia Agraria di Portici, 8: 225-227.

Klingstedt, H., 1936. Die Coniopterygiden der Kanarischen Inseln. Commentationes Biologicae, 6(8): 1-5.

Hölzel, H., 1998. Zoogeographical features of Neuroptera of the Arabian peninsula. Acta Zoologica Fennica, 209: 129-140.

MeINANDER, M., 1963. Coniopterygidae (Neuroptera) from Morocco. Notulae Entomologicae, 43: 92-164.

MeinANDER, M., 1965. Some Neuroptera from the Canary Islands and the Spanish Sahara. Notulae Entomologicae, 45: 53-60.

Meinander, M., 1972. A Revision of the family Coniopterygidae (Planipennia). Acta Zoologica Fennica, 136: 1-357.

Meinander, M., 1974. Coniopterygidae from Madagascar (Neuroptera). Notulae Entomologicae, 54: $60-63$

Meinander, M., 1975a. Coniopterygidae from West Africa (Insecta: Neuroptera). Entomologica Scandinavica, 6: 247-252.

Meinander, M., 1975b. Coniopterygidae from South Africa (Neuroptera). Notulae Entomologicae, 55: 81-85.

Meinander, M., 1976. Coniopterygidae from Africa (Neuroptera). Notulae Entomologicae, 56: 85-88.

Meinander, M., 1981. A review of the genus Coniopteryx (Neuroptera,Coniopterygidae). Annales Enomologici Fennici, 47: 97-110.

MeInANDER, M., 1983. The Coniopterygidae (Neuroptera) of southern Africa and adjacent Indian Ocean Islands. Annals of the Natal Museum, 25(2): 475-499.

MeInANDER, M., 1990. The Coniopterygidae (Neuroptera,Planipennia). A check-list of the species of the world, descriptions of new species and other new data. Acta Zoologica Fennica, 189: 1-95.

Meinander, M., 1996. Coniopterygidae from subSaharan Africa. In: Proceedings of the Fifth International Symposium on Neuropterology. Toulouse: 187-192.

Meinander, M., 1998a. Coniopterygidae (Neuroptera) from the Mediterranean Region and Iran. Journal of Neuropterology, 1: 23-31.

MeInANDER, M., 1998b. Coniopterygidae (Neuroptera) from southern and eastern Africa. African Entomology, 6(1): 117-146.

Monserrat, V.J., 1976. Un nuevo coniopterígido en España. Nouvelle Revue d'Entomologie, 6(1): 97-100.
MonserRat, V. J., 1985. Contribución al conocimiento de los neurópteros de Marruecos (Insecta, Neuroptera, Planipennia). Mediterránea (Serie Biologica), 8: $73-82$.

MonserRat, V.J., 1989. Contribución al conocimiento de los Coniopterígidos de Rio Muni (Guinea Ecuatorial) (Neuropteroidea, Planipennia: Coniopterygidae). Annali del Museo Civico di Storia Naturale di Genova, 87: 157-181.

MonserRat, V.J., 1995. Nuevos datos sobre los coniopterígidos de las regiones paleártica y afrotropical. (Neuroptera: Coniopterygidae). Graellsia, [1994], 50: $109-127$.

MonserRat, V.J., 1996. Nuevos datos sobre los coniopterígidos de Yemen (Neuroptera: Coniopterygidae). Annali del Museo Civico di Storia Naturale di Genova, 591: 1-26.

MonserRat, V.J., 1998. Nuevos datos sobre los coniopterígidos de Zimbabwe y Zambia (Neuroptera: Coniopterygidae). Journal of Neuropterology, 1: 5- 15.

Monserrat, V.J. \& DíAZ-ArandA L.M., 1988. Contribución al conocimiento de los coniopterígidos de la Isla de Bioco (Guinea Ecuatorial) (Neuropteroidea, Planipennia: Coniopterygidae). Revue de Zoologie Africaine, 102: 493-502.

Monserrat, V.J. \& DíAZ-Aranda L.M., 1990. Nuevos datos sobre los coniopterígidos ibéricos (Neuroptera: Coniopterygidae). Neuroptera International, 6(1): 39-49.

NAVÁs, L., 1912. Insectos Neurópteros nuevos. Verhandlung VIII Internationale Zoologische Kongress, Graz: 746-751.

Oнм, P., 1963. Zur Kenntnis der Coniopterygiden der Kanarischen Inseln (Neuroptera). Zoologischer Anzeiger, 171(5/8): 264-272.

Онм, P., 1965. Beiträge zur Kenntnis der Gattung Helicoconis Enderlein 1905 (Neuroptera Coniopterygidae) nebst Diagnose zweier neuer Arten aus dem schweizerischen Nationalpark. Ergebnisse der wissenschaftlichen Untersuchungen im schweizerischen Nationalpark, 10: 171-207.

OHм, P., 1986. Eine neue Parasemidalis-Art von den Kanarischen Inseln: Parasemidalis similis n.sp. (Planipennia: Coniopterygidae). Entomologische Zeitschrift, 96(22): 327-331.

OHM, P. \& HöLzel, H., 1997. Beitrag zur Kenntnis der Neuropterenfauna der Maskarenen (Neuroptera: Coniopterygidae, Hemerobiidae, Chrysopidae, Myrmeleontidae). Entomofauna, 18(17): 221-236.

OHм, P. \& HöLzel, H., 1998. A contribution to the knowledge of the neuropterous fauna of the Comoros: The Neuroptera of Mayotte. Acta Zoologica Fennica, 209: 183-194.

OhM, P. \& Hölzel, H., 1999. Die ConiopterygidenGattung Semidalis Enderlein auf den Mittelatlantis- 
chen Inseln (Neuropteroidea: Planipennia: Coniopterygidae). Reichenbachia, 33(30): 231-237.

SzIRÁKI, G., 1994. Coniopterygidae from the Afrotropical Region (Neuroptera). Acta Zoologica Academiae Scientiarum Hungaricae, 40(2): 171-184.

SzIRÁKI, G., 1997. Data to the Coniopterygid fauna of Yemen, with description of twelve new spacies (Neuroptera: Coniopterygidae). Acta Zoologica Academiae Scientiarum Hungaricae, 43(3): 271294.

SzIRÁKI, G., 1998. Zoogeographic relations of South Asian coniopterygids (Neuroptera, Coniopterygidae). Acta Zoologica Fennica, 209: 249-254.
SzIRÁKI, G. \& Greve L., 1996. Some Coniopterygidae (Neuroptera) from a mountain rainforest of Tanzania. Acta Zoologica Academiae Scientiarum Hungaricae, 42(1): 81-88.
Recibido, el 11-X-2001 Aceptado, el 2-VII-2002 Publicado, el 5-IX-2002 